\title{
Qualitative Analysis of Effects Managerial Ability and Environmental Industry to Performance of the Firm
}

\author{
Ibnu Hajar ${ }^{1}$, Nitri Mirosea ${ }^{1}$, Ambo Wonua Nusantara ${ }^{1} \&$ Buyung Sarita $^{1}$ \\ ${ }^{1}$ Economic Faculty of Haluoleo University, South East Sulawesi, Indonesia \\ Correspondence: Buyung Sarita, Economic Faculty of Haluoleo University, South East Sulawesi, Indonesia. E-mail: \\ buyungsarita_buyung@yahoo.com
}

Received: May 21, 2013

Accepted: June 13, 2013

Online Published: June 17, 2013

doi:10.5430/afr.v2n3p37

URL: http://dx.doi.org/10.5430/afr.v2n3p37

\begin{abstract}
This study aimed to analyze the effect of managerial capacity and industry environment to performance of companies in the small industrial of teak wood furniture in Southeast Sulawesi. The research used census sampling of 143 managers or owners of the company as respondents. The analysis in this research is descriptive and qualitative. The result of the analysis showed that high managerial skills in specialized skills and moral values of trust can anticipate industrial environmental uncertainty by implementing alliances strategies to improve company performance. Specialized expertise and high moral values are essential to managerial skills in order to improve company's responsiveness to enhance company's capacity resource and cost production efficiency. Firstly, it can be more responsive to customer need, create quality in product or service, imitating product, and accelerate system to speed-up production process. Then, secondly, being efficient in cost production to formulate and implement proper competitive strategic to improve sales volume, profit and asset.

It is suggested that owner and manager of small industrial in teak furniture firstly need to improve managerial skills in term of conceptual abilities, interpersonal skills, and technical skills. Then second important thing is trust, in term of moral values to make cooperation to third parties and formulating strategic to improve the performance of the firm.
\end{abstract}

Keywords: Managerial ability, Environmental industries, The company's performance

\section{Introduction}

Small business development has long been discussed and researched, both in developed and in developing countries. The benefits of it can contribute significantly to the economic development of the nation. According to Manolova (2001) that these businesses are popular choices entrepreneurs because they typically require fewer assets, minimal financial investment, and few employees. Small businesses in many developing countries are tools to economic growth because small businesses are potentially encourage diversification of economic activities and raised the opportunity of work seeker.

Small businesses have the advantage of being one of the main pillars of economic development in term of economic democracy, driver of diversification of economic activity and higher work force need. Even though, small businesses facing higher risky in failure and have barriers to be imitated, which means that small businesses have lower ability or resources in term of competitive advantage (Zahra and Bogner, 2000). Empirical phenomena indicates that by 2010, the number of small and medium enterprises (SMEs) reached 51.3 million units and was able to absorb employment by 91.8 million people. However, the contribution of small and medium enterprises (SMEs) on the formation of the gross domestic product (GDP), its contribution is only about 15 percent and exports contributed around Rp.143 trillion, or about 15 percent of Indonesia's total exports in 2010.

The growth of small and medium enterprises (SMEs) in the industrial sector is moving slowly, it is due to the industrial raw materials which has not been optimally used and processed to provide addition value to the industry. Most of the potential economic resources are directed to the trade sector both export trade, as well as inter-island trade. In 2010, the tertiary sector accounted for 45 percent, 37 percent of the primary sector and the secondary sector or the industrial sector 19 percent in Southeast Sulawesi provincial GDP (World Bank, 2012).

The total share of small and medium enterprises included small wooden furniture industry in Southeast Sulawesi province had contributed in small portion to the gross regional domestic product (GRDP) in 2005-2009, which is less 
than 1 percent. This phenomenon needs to be studied, because of two reasons: firstly, hand-made teak furniture is a typical business which has long operated in Southeast Sulawesi by relying on comparative advantage of indigenous teak wood. Secondly, raw materials are valuable and rare, but it has shown that it may not provide significant added value for small businesses wooden furniture. So the source of comparative advantage teak can't be utilized by small wooden furniture industry as a source of competitive advantage. From the two reasons above, It can be taken as note that there are many interrelated factors influencing performance of small wooden furniture industry in Southeast Sulawesi province, namely managerial capability and industrial environments.

\section{Literature Review}

Research using resource-based view preceded by Penrose (1959) stated that the company's growth is limited by the ability of a manager to coordinate resources. Strategic decisions and the selection of appropriate resource owners / managers in small firms will determine the final performance of the company. Managerial skills are the knowledge, skills, and experience that intangible that can be used by managers (Hitt et al., 2001: Kor, 2003). Resource-based theory suggests that resource companies should be valuable, rare, unique, and can't be copied should lead to a competitive advantage.

On the other hand, Porter (1980) competitive strategy framework identifies five forces in the industry; intensity of competition in the industry, threat of new entrants, threat of substitute products, bargaining power of suppliers, bargaining power of customers. Those five forces are in industrial environment which determine potential profit in an industry. Furthermore, Porter (1985) defines competitive strategy as a business position to maximize value for the company compared to competitors by pursuing generic strategies as follows: cost leadership, differentiation, and focus.

Management theory explains that management involves coordination and supervision of the work of others (Robbins and Coulter, 2010). From another point of view described by Daft (2010), Management is achievement of organizational goals efficiently and effectively through planning, leadership, and controlling organizational resources.

Manager coordinates and controls the work of others, so that organizational goals can be achieved. Managerial skills of a manager can be defined as: knowledge, experience, and expertise that can be used by managers (Kor, 2003). From the perspective of strategy, managerial ability comes from two main sources, namely domain expertise and skill resources. Domain expertise which refers to an understanding of the industry and the manager of the company's strategy, namely: product, market, environmental tasks, and routines (Sirmon et al, 2007).

Based on empirical facts and theoretical concepts that have been proposed, it is interesting to study phenomena; which factors can influence the performance of small-scale industries teak wood furniture in Southeast Sulawesi ? Is that raw material or nature resource factors? or particularly managerial skills entrepreneur industrial or environmental factors that can increase the performance of the company? Based on these reasons, it is interesting to perform studies by integrating two complementary perspectives, the resource-based view and the view of the organization of industry in small industry teak furniture in the Southeast Sulawesi.

The problem in this study were: (1) How managerial skills employers can improve the performance of the company, (2) How does the performance of the industrial environment firm. Aims this study was to analyze the effect of managerial capacity and industrial environment on the performance of the firm.

Based on the formulation of the problem and research objectives, the proposition may be submitted as follows:

Robbins and Coulter (2010) states when a manager wants to succeed in his quest as seen from the performance, then a manager must possess and carry: (1) management functions, (2) the role of management, and (3) management skills. Mahoney (1995) suggest that managerial skills in combination with a variety of typical resource companies together will produce profits of companies involved in the competition. Haber and Reichel (2007) found that human capital entrepreneurs positive effect on business performance. Holcomb et al. (2009) found that the positive effect of managerial skills organizational performance.

Based on the results of earlier studies that have been done in 2010 that the low corporate profits on small industries of teak furniture in Southeast Sulawesi due to lack of managerial skills entrepreneur, among others: (a) low level of formal education, mostly junior high school, (b) lack of knowledge of planning (c) low level of managerial skills.

Proposition 1: The higher the managerial skills of entrepreneurs, the higher the performance of the firm.

Porter (1985) states that companies need to understand or assess existing competition pattern and strength of competition in the industry, because it determines the potential earnings power of the company in the industry, 
namely the threat of new entrants, threat of substitute products, supplier bargain, bargain shoppers, the intensity competition in the industry. Muryati (2004) found that external factors and significant negative effect on performance. Ramakrishnan et al. (2010) found that the regulatory environment negatively affect economic performance.

Factual findings showed that the environment in the wooden furniture industry is very dynamic in term of forces of industry environment. Firstly, the power of teakwood suppliers is very strong, it is avaiable and traded in large amount. Secondly, customer preference has changing rapidly. The other important threat is from of large competitors that offer quality products and design which more interesting. Lastly is threat from substitute products such as rattan, aluminum, and plastic products.

Proposition 2: The more dynamic the industry, the more it will degrade the performance of the firm.

\section{Objectives:}

The objectives of this research are:

1. To measure and analyze the effect of managerial ability to firm performance of small wooden furniture industry in South East Sulawesi.

2. To measure and analyze the effect of environment industry to firm performance of small wooden furniture industry in South East Sulawesi.

\section{Methods}

The population in this study is all business units of small industries of teak furniture units consist of 143 business, which are: Kendari city (41 business entities), and four regencies namely: Muna (37 business entities), Konawe Selatan (34 business entities), Kolaka Utara (18 business entities) and Konawe Utara (13 business entities), which situated in Southeast Sulawesi. Determination of the population based on the number of small industries handicraft wooden furniture that meet several criteria the Central Statistics Agency (BPS) and the Law criteria Number 20 of 2008 on micro, small and medium enterprises. Sampling method saturated sample (census), where all business units small craft wooden furniture industry in Southeast were sampled.

The respondents in this study are the owners of a small industrial units hand-made teakwood furniture, who work also as a manager in their business unit which located spread across districts / municipalities in the province of Southeast Sulawesi. Data collected using questionnaires and in-depth interviews (in-depth interviews) to obtain information from a number of key person who has been chosen as an informant on the basis of specified criteria. Methods of analysis used in the study was descriptive and qualitative analysis to help clarify the picture and the phenomena that occur in a small industrial teak wood furniture in Southeast Sulawesi.

\section{Results}

\subsection{Descriptive Analysis of Research Variables}

Descriptive analysis is needed in order to get respondents's perception of the questions and statements given about the variables used in this research. Descriptive analysis was calculated based on the percentage of respondents' answers to the research questions using the average (mean) of each indicator is proposed to describe the perceptions of all respondents. Based on the average (mean), the perception of the respondents do interpretations using three criterias-box method (Ferdinand, 2006: 292), namely, 1.0 to $2.3=$ low, 2.4 to $3.7=$ moderate, 3.8 to $5.0=$ high. From these criteria, it can be determined respondents' perceptions index variables in the study, namely: Managerial Ability (X1), Environment Industry (X2), and Firm Performance (Y).

\subsection{Managerial Ability Description}

Managerial skills is shown by the ability to create a business plan, build teamwork, moving employees, business relationships, and oversight in an effort to gain a competitive advantage for the company through improved organizational capabilities. Therefore, the managerial skills of a manager in carrying out the functions of management can create value for the company through cost efficiency; improve product quality and service, the innovation of the production process. The response to the managerial skills of managers using questionnaires measuring instruments are presented in the following table: 
Table 1. Managerial Ability Variables Description

\begin{tabular}{|c|c|c|c|c|c|c|c|}
\hline \multirow{2}{*}{\multicolumn{2}{|c|}{ Indicator }} & \multicolumn{5}{|c|}{ Answer ( \%) } & \multirow[t]{2}{*}{ (Mean) } \\
\hline & & 1 & 2 & 3 & 4 & 5 & \\
\hline $\mathrm{X} 1.1$ & Business Plan & 0.0 & 4.2 & 24.5 & 61.5 & 9.8 & 3.77 \\
\hline $\mathrm{X} 1.2$ & Team-work building & 0.0 & 0.0 & 8.4 & 73.4 & 18.2 & 4.10 \\
\hline $\mathrm{X} 1.3$ & Persuading employees & 0.0 & 0.0 & 6.3 & 72.7 & 21.0 & 4.15 \\
\hline $\mathrm{X} 1.4$ & Creating business-relation & 0.0 & 0.0 & 8.4 & 69.2 & 22.4 & 4.14 \\
\hline $\mathrm{X} 1.5$ & Monitoring & 0.0 & 0.0 & 2.1 & 55.9 & 42.0 & 4.40 \\
\hline
\end{tabular}

Sources: Primary data, processed

Empirical evidence showed that ability are well perceived $(X .1=4: 11)$ by the managers and owners. This illustrates the high managerial skill is due to interpersonal and technical skills through the experience of business. These capabilities include the ability to control or monitoring, to motivate employees, the ability to establish a business relationship, and teamwork skill.

\subsection{Description of Industrial Environment}

The dynamics of the industry environment can bring an opportunity or a threat to the company's operations. Industrial environment is a function of the five forces of competition, namely the threat of new entrants firms, bargaining power of suppliers, bargaining power of buyers, threat of substitute products, and intensity of competition in the industry. Response, it seems the following table:

Table 2. Description of Industrial Environment Variables

\begin{tabular}{|c|c|c|c|c|c|c|c|}
\hline \multirow{2}{*}{\multicolumn{2}{|c|}{ Indicator }} & \multicolumn{5}{|c|}{ Answer (\%) } & \multirow[t]{2}{*}{ (Mean) } \\
\hline & & 1 & 2 & 3 & 4 & 5 & \\
\hline $\mathrm{X} 2.1$ & Threat of new entrants & 2.8 & 55.2 & 12.6 & 24.5 & 4.9 & 2.13 \\
\hline $\mathrm{X} 2.2$ & Bargaining power of suppliers & 0.7 & 55.9 & 20.3 & 20.3 & 2.8 & 2.19 \\
\hline $\mathrm{X} 2.3$ & Substitute products & 2.1 & 60.8 & 16.1 & 16.8 & 4.2 & 2.20 \\
\hline $\mathrm{X} 2.4$ & Bargaining power of customer & 0.0 & 49.0 & 17.5 & 30.1 & 3.5 & 2.28 \\
\hline $\mathrm{X} 2.5$ & $\begin{array}{l}\text { Intensity of competition in the } \\
\text { industry }\end{array}$ & 2.1 & 54.5 & 8.4 & 29.4 & 5.6 & 2.22 \\
\hline
\end{tabular}

Mean of Industrial Environment $(X 2)=2.24$

Sources: Primary data processed

Table 3 above explains that most of the managers of small teakwood furniture industry in Southeast Sulawesi, providing a low perception of the environment industry with an average score of 2.24.

It can be seen from the score, that industry environment are perceived the dynamic is very weak, in term of uncertainty. Nevertheless, the bargaining power of customers has a potential effect on the company, because customers have a preference on the model, brand, quality, durability and the utility of goods.

\subsection{Description of Firm Performance}

Performance of the company is a success that has been achieved by a firm in realizing the objectives or performance of the firm. Mostly the performance of the firm is measured by financial approach, for example by indicators of Return On Investment (ROI). Therefore, in this study, the measurement of the performance of the firm, use of 
indicators, namely; sales growth, profit growth, and the Asset growth. The response of the managers on the performance of companies using questionnaires measuring instruments are presented in the following table.

Table 3. Variable Description Firm Performance

\begin{tabular}{|c|c|c|c|c|c|c|c|}
\hline \multirow{2}{*}{\multicolumn{2}{|c|}{ Indicator }} & \multicolumn{5}{|c|}{ Answer (\%) } & \multirow[t]{2}{*}{ (Mean) } \\
\hline & & 1 & 2 & 3 & 4 & 5 & \\
\hline Y1.1 & Sales growth & 0.0 & 1.4 & 22.4 & 69.2 & 7.0 & 3.82 \\
\hline Y1.2 & Profit growth & 0.0 & 1.4 & 23.8 & 64.3 & 10.5 & 3.84 \\
\hline Y1.3 & Asset Growth & 0.0 & 1.4 & 22.4 & 71.3 & 4.9 & 3.80 \\
\hline
\end{tabular}

Mean of Firm Performance $(\mathrm{Y})=3.82$

\section{Sources: Primary data processed}

Table above explains that most of the managers of small industry of teakwood furniture provide a high perception of the performance of the company, with an average score of 3.82. Positive growth of this industry is showed by earnings growth, sales growth and asset growth for the last 3 years.

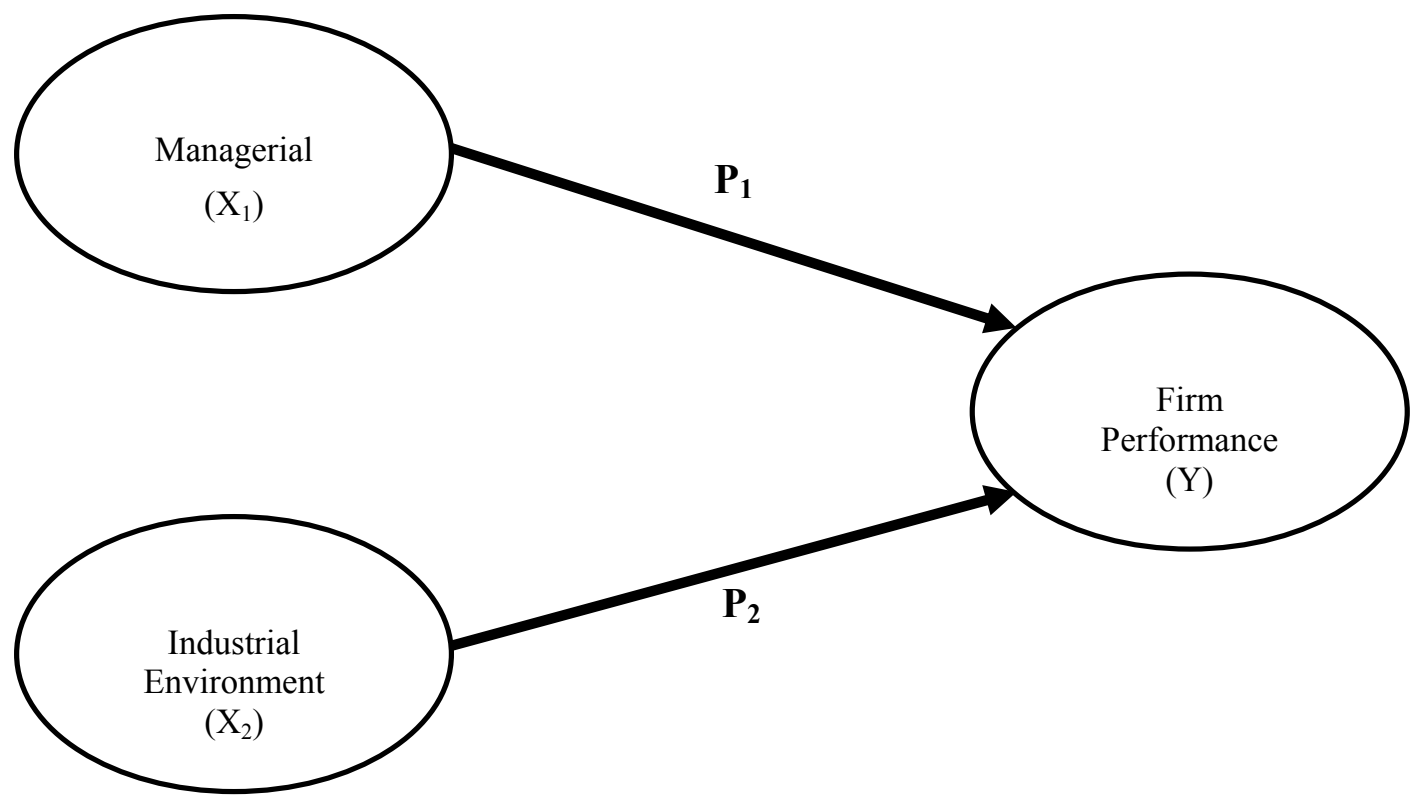

Figure 1. Research Model Frame Work

\subsection{Analysis of Qualitative Information}

In order to enrich the data and have deeper understanding of the empirical findings, the researchers attempted to perform a qualitative analysis focusing on the facts or events done by the owner or manager of wooden furniture company in Southeast Sulawesi to grow its business, and the result are as follows:

1. Key informan 1, Mr. Haji Kamaruddin Sata Dg. He stated that his reason on having this business was because to support family and his 7 (seven) children. He started his own business in 1980. His committed should be diligent, industrious, honest, clean and good words to make the business growing. He started the business with small capital to purchase raw materials (teak), it was Rp.350.000 Rp.200.000, -. But now he already has 18 shops.

According to the owner of the company or the story may be obtained Teak Kingdom theme: "Building a business with moral values". Theme, explaining that the success of a firm in the long run is determined moral values shared by the owner of the firm in conjunction with customers, employees, suppliers, and society at large.

2. Key informan 2, Mr. Idi Sutardi, S.Pd, who started his business in 1993. He tried with capital skill carpenter taught by parents as a carpenter in the village district Watubangga Kolaka. He believes that business success is largely determined by the ability of the owner to master the technology used in the business. He was helped by 
families in the village who are unemployed to do the carpenter work. As a result, until now he succeed and shop, land, cars, and teak plantation which expected to anticipate the scarcity of raw materials.

According to the owner of the firm that " Carpenter skills is primary to open a teak wood business." Theme, explaining that his successful business depend to the technological skill they used in the company,it is needed to direct and guide employees in making a product, and to control production efficiently. Besides that, he also said that successful business leaders have when moral values such as honesty, responsible, and on time to customer order.

3. Key informan 3, Mr. Rahmat Suprih, who started his business in 1997, he had a carpentry background and prior to opening his own business. He opened a business based on motivation that he have carpenter skills and support of his friends with a profit-sharing agreement. He sales work-in process products to the buyers of furniture business in Kendari. As a result he is now have a teak plantation, sawmill machinery, and has several vehicles that he use to transport raw materials and semi-finished products as well as in both South of Konawe and Kendari.

According to Rahmat Suprih, explaining that a successful business is the main capital of trust, because if we have the moral values of trust, then we can work with suppliers of raw material, competitors, customers, and our own employees.

Based on the statements of the respondents, there is something interesting in exploring the phenomenon interpreted in the success of business owners in Southeast Sulawesi wooden furniture. This phenomenon suggests that the owners of wooden furniture company build its business with two keywords, the skills, and confidence. Capabilities and values, can shape the behavior of the owners / managers of wood furniture company in making changes to building his business to success. In a rapidly changing world, managers need improved skills to diagnose the reluctance to change and have adequate methods to address them. An acceleration of the changes will result in an increased need for reorganization (Ubud Salim, 1996).

With respect to behavioral changes (changes of behavior), then according Mc.Cleland in Alma (2011), there are three basic nature of every human being, namely; need of power, need of affiliation, and need of achievement. The most important trait possessed by a manager in the building business is the motive to succeed (need of achievement) and supported by the motive to work (need of affiliation). Therefore, a successful manager must have a desire for high achievement by trying to work hard, improve their skills, good at working with people, good at making decisions, and maintain trust, both between managers and subordinates, and between managers with related parties an interest outside the company. Wibowo (2012) states that the trust or the trust is the most cherished values in human relationships. Trust is the confidence people have on others.

Skill and confidence are intangible assets which consist of value, rare, hard to imitate, and irreplaceable (Vrin). Skills reputation and trust are held by the owner and utilized in managing its business as follows;

1. Skill in carpentry is valuable asset because of the background of their carpentry skill that will bring them to understand technology industrial furniture production process. It helps and benefit in monitoring and move employees in an effort to repair the mechanism of action, adjust the production process technology, designing quality products and responsive to consumer desires.

2. Trust is the moral values that should be owned by someone in the business activity, since business activity is the relationship between managers with employees, customers, suppliers, and society at large. Faith contains moral values or attitudes that could affect the correctness behavior in their daily activities, such as honest and trustworthy nature. Furthermore trait of honesty is no deception, broken promises and lies in producing a product and services. While the nature of the mandate implies responsibility, and courtesy toward subordinates, and interested parties such as suppliers, competitors, distributors, and customers.

\subsection{The results provide theoretical implications as follows:}

1. Empirical findings in this study reinforce the importance of the concept of managerial ability as a source of value creation for the company in the context of small-scale industries. The concept of managerial skills in the resource-based view of research initiated by Penrose (1959) said that the company's growth is based on the ability of managers to coordinate resources and strategic decisions for the selection of the appropriate resource managers determine the final performance of the company. Furthermore, Barney (1991) says that the ability of managers to understand and effectively use corporate resources is a potentially valuable resource to generate a sustainable competitive advantage for the company. These findings provide a perspective in the development of management theory research strategy for developing research-based resource views expressed in this research Manolova (2001); Man et al. (2002); Sirmon et al. (2003), Haber \& Reichel (2007); Holcomb et al. (2009), and Kamukama et al. (2011) stated that managerial skills are sources of competitive advantage for the company, because it can create 
organizational capabilities, formulate an appropriate competitive strategy and ultimately to improve the performance of the company.

2. The findings of this study to develop the importance of the concept of Porter's five forces industry (1985) in the context of small-scale industries that companies need to understand the pattern of the existing competition and the company's position in the competition. Five power industry, including: (1) competition between firms within the industry, (2) the threat of entry of new competitors, (3) the threat of substitute products, (3) bargaining power of suppliers, and (5) bargaining power of buyers. These findings provide a new perspective to the view of the industry organization for this research study developed $\mathrm{Wu}$ (2009) says that if the company faces volatile industry environment is weak or moderate, the company can gain a competitive advantage, but if the company faces higher volatility of the industry environment, the company competing advantage is reduced. Furthermore, Muryati (2004); Ramakrishnan et al. (2010) stated that the external environment negatively affect the company's performance.

\section{Adding Value of the Result:}

The results of this study are expected to contribute to the development and empowerment of small-scale industries in Southeast Sulawesi province, as follows:

1. For local government in making policy and program development and empowerment of small scale industries through education and training managerial skills and build confidence, especially strategic planning for managers or owners of small industrial companies on understanding the functions of management, moral values of trust, organizational skills, an understanding of the industry environment, and the formulation of strategies to improve the performance of the company's cooperation.

2. For the managers of small firms wooden furniture industry in developing a business that managerial skills and moral values of trust is very important for managers in understanding and managing resources in order to create value for the company and understand the uncertainty and intensity of competition among companies in the furniture industry to formulate and implement strategic partnerships to increase sales, profits, and assets of the company.

\section{Conclusions}

Specialized expertise and high moral values are essential to managerial skills in order to improve company's responsiveness to enhance company's capacity resource and cost production efficiency. Firstly, it can be more responsive to customer need, create quality in product or service, imitating product, and accelerate system to speed-up production process. Then, secondly, being efficient in cost production to formulate and implement proper competitive strategic to improve sales volume, profit and asset.

It is suggested that owner and manager of small industrial in teak furniture firstly need to improve managerial skills to strengthen business by formulating strategies in short and long term planning to be more competitive in the industry of teakwood. Then second important thing is trust, in term of moral values to the customer and also to make cooperation to third parties to improve the performance of the firm.

It also need Local Government's hand to strengthen small teak furniture industry in education and training and also comparative studies such as: (a) training in managerial skills (b) training in carpentry skills, (c) comparative study to other furniture industries in Jepara (Central Java) and Pasuruan (East Java).

\section{References}

Alma, Buchari. (2011). Kewirausahaan, cetakan ketujuhbelas, Penerbit Alfabeta,Bandung.

Barney, J. (1991). Firm Resources and Sustained Competitive Advantage. Journal of Management. 17 (1): 99-120. http://dx.doi.org/10.1177/014920639101700108

Bank Dunia, (2011). Analisis Keuangan Publik Provinsi Sulawesi Tenggara, 2012. Kinerja Pelayanan Publik dan Tantangan Pembangunan di Bumi Haluoleo, Jakarta.

Hitt,MA, Ireland RD, \& Hoskisson,RE. (2001). Strategic Management: Competitiveness and Globalization, $4^{\text {Th }}$ Edition: Concepts, South-Western College Publishing, USA.

Holcomb, T.R, Holmes JR,R.M, \& Connelly,B.L. (2009). Making the most of what you have: Managerial ability as a source of resource value creation. Strategic Management Journal, 30: 457-485. http://dx.doi.org/10.1002/smj.747

Kamukama, N, Ahiauzu,A, \& Ntayi,J.A. (2011). Competitive Advantage :Mediator Of Intelectual Capital And Performance, Journal of intellectual capital, Vol 12 No.1, 2011. Pp. 152-164. http://dx.doi.org/10.1108/14691931111097953 
Kor YY, (2003). Experience-Based Top Management Team Competence And Sustained Growth. Organiation science, 14 (6):707-719.

Mahoney,J.T. (1995). The Management Of Resources And The Resource Of Management. Journal of Business Research, 33: 91-101. http://dx.doi.org/10.1016/0148-2963(94)00060-R

Manolova. T. (2001). The Mediating Role of Strategy on Small Firm Performance. Working Paper Doctoral Strategy and Policy. Boston University. Scholl of Management.

Man, T.W.Y \& Chan, K.F. (2002). The Competitiveness Of Small And Medium Enterprices: A Conceptualization With Focus On Entrepreneurial Competencies. Journal of Business Venturing, 17, 123-142. http://dx.doi.org/10.1016/S0883-9026(00)00058-6

Muryati. (2004). Intensitas Strategi Bersaing Dan Kinerja Ekspor Pada Industri Kecil Produk Kerajinan Kayu Di Propinsi Jawa Timur,Disertasi tidak dipublikasikan, PPSUB, Malang.

Porter, M.E. (1985). Competitive Advantage: Creating and Sustaining Superior Performance. New York: The Free Press.

Ramakrishan,R,Black,A, Nath Prifhwiraj, \& Muyldermars,L, (2010). Impact Of Environmental Regulations On Innovation And Performance In The UK Industrial Sector. Management Decision, Vol 48, No 4, pp 1493-1513.

Reichel, A., Haber, S. (2007). The Cumulative Nature Of The Entrepreneurial Process: The Contribution Of Human Capital, Planning And Environment Resources To Small Venture Performance. Journal of Business Venturing, 22, 119-145. http://dx.doi.org/10.1016/j.jbusvent.2005.09.005

Sirmon DG, Hitt MA, Ireland RD. (2007). Managing Firm Resources In Dynamic Environments To Create Value: Looking Inside The Black Box, Academy of Management Review, 32 (1): 273-292. http://dx.doi.org/10.5465/AMR.2007.23466005

Ubud Salim. (1996). Memilih Strategi-Strategi Perubahan, Lintasan Ekonomi: Majalah Ilmiah Fakultas Ekonomi Universitas Brawijaya. Edisi September-Desember.

Wibowo. (2012). Manajemen Perubahan, Edisi Ketiga, Rajawali Pers,Jakarta. 